\title{
Self-Assembled Copper(I) Complexes of Symmetric Dithioether Ligands
}

\author{
Tae Ho Kim, Garam Park, Yong Woon Shin, Ki-Min Park, Myong Yong Choi, and Jineun Kim
}

\author{
Department of Chemistry (BK21) and Research Institute of Natural Science, Gveongsang National Cniversitw, \\ Jinju 660-701, Korea. ${ }^{*}$ E-mail: jekimáagmac.kr \\ Received October 1, 2007
}

Key Words : Copper(I) iodide. Coordination polymer, Dithioether ligand, Crystal structure, Luninescence

Coordination polymer is being investigated very actively due to many interesting structural features and useful properties such as catalỳsis. photoluminescence, magnetism. and adsorption. ${ }^{1-4}$ Copper(I) halides are capable of adopting various structural motifs. ${ }^{5-\delta}$ Recently, we have focused on $\mathrm{Cu}(\mathrm{I})$ coordination polymers with dithioether ligands. During our investigation on $\mathrm{CuI}$ reaction with dithioether ligands. we examined the structural diversity of copper(I) iodide complexes by symmetric and asymmetric dithioether ligands ${ }^{6 a .9 .13}$ Herein we report a discrete complex (1) two(2). and one-dimensional (3) coordination polymers based on 1.2- $\left(\mathbf{L}^{\mathbf{1}}\right)$. 1.3- $\left(\mathbf{L}^{2}\right)$, and 1.4-bis(cyclohexỵlthiomethỵl)benzene $\left(\mathbf{L}^{3}\right)$. respectively (Scheme 1).

Three bidentate dithioether ligands $\mathbf{L}^{1}-\mathbf{L}^{3}$ were synthesized by the reaction of cyclohexanethiol and each corresponding bis(bromomethyl)benzene. An equimolar amount of copper(I) jodide and $\mathbf{L}^{\mathbf{1}}$ was dissolved in acetonitrile. Vapor diffusion of diethyl ether into acetonitrile solution of the reactants resulted in a colorless X-ray quality crystal 1 . Single-crystal $X$-ray analy sis ${ }^{11}$ revealed that 1 was a formula $\left[\mathrm{Cu}_{2} \mathrm{I}_{2} \mathbf{L}_{2}\right]$ and its gross geometry of $\mathbf{1}$ can be described as a sandwich type complex (Figure 1). The asymmetric unit

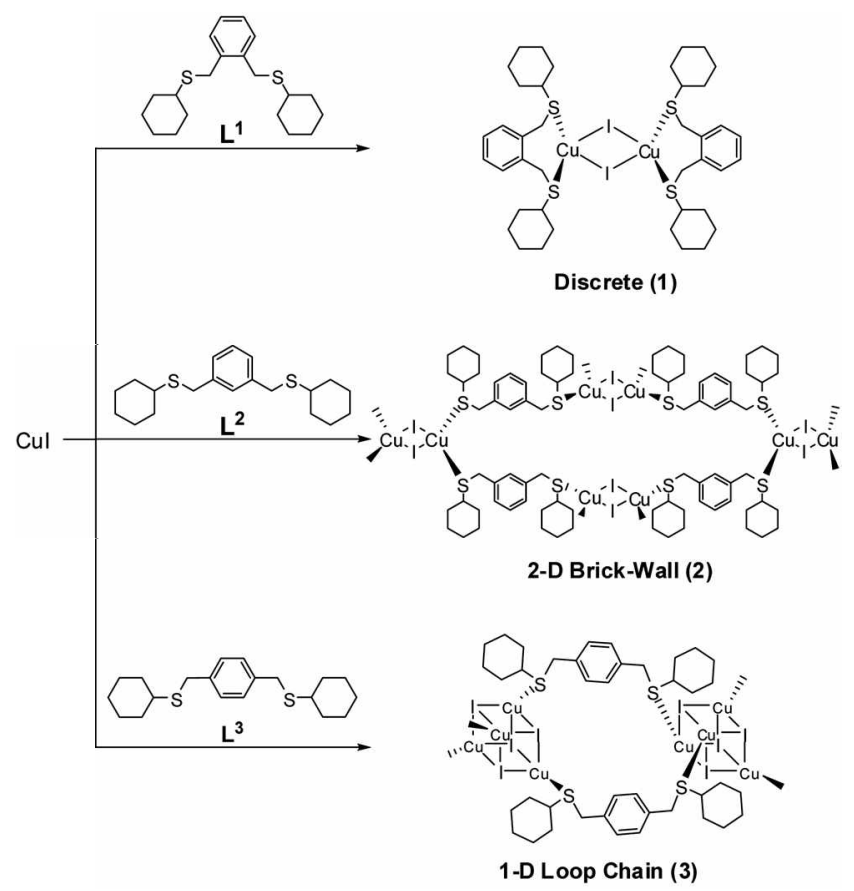

Scheme 1. Syntheses of $\mathrm{Cu}(\mathrm{I})$ complexes 1-3. consists of one $\mathrm{L}^{1}$ and one copper(I) iodide. A sandwich unit of 1 contains two asyimmetric units where two ligands are bridged by rhomboid $\mathrm{Cu}-\mathrm{I}_{2}-\mathrm{Cu}$ linkers. The copper(I) is tetrahedrally coordinated by two sulfur donors from each ligand and two $\mu_{-}$-iodide atoms. The S-Cu and $\mathrm{Cu}-\mathrm{I}$ bond distances are reasonably similar to those reported in other complexes. ${ }^{5} \mathrm{i}$

Slow evaporation of acetonitrile solution of $\mathrm{L}^{2}$ with an equivalent amount of copper(I) iodide afforded a yellow crystal 2 that was suitable for an X-ray analy sis (Figure 2). ${ }^{\text {] }}$ Polymer 2 can be described as a 2 -dimensional (2D) infinite brick-wall type complex with formula $\left[\mathrm{CuIL} \mathbf{L}^{2}\right]_{i \text {. }}$. The asymmetric unit consists of one $\mathbf{L}^{2}$ and one copper(I) iodide. A single brick unit of $\mathbf{2}$ contains four asymmetric units where each ligand is interconnected with the rhomboid $\mathrm{Cu}-\mathrm{I}_{2}-\mathrm{Cu}$ linkers alternately (Figure 2b). The copper(I) is tetrahedrally coordinated by two sulfur donors from two adjacent ligands and two $\mu_{2}$-iodide atoms. In this case, the preference of 2D sheet is probably due, at least in part. to the planarity of four sulfur donors (S1. S1B, S2A and S2C) related by an inversion symmetry. which also applies to that of 1 . However, the fact that $\mathbf{L}^{1}$ has not only shorter distance between

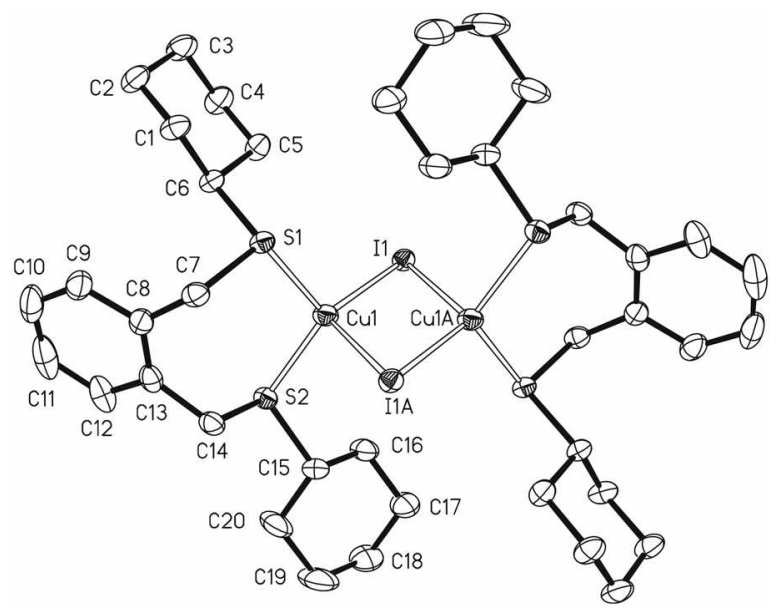

Figure 1. Ortep diagram of 1 , showing coordination environment. Hydrogen atoms are omitted for clarity. Selected bond lengths $(\AA)$ and bond angles ("): Cul-CulA 2.9560(5), S1-S2 3.8797(6), CulS2 2.3188(5). Cul-SI 2.3200(5), Cul-Il 2.5804(3), Cul-IlA $2.7285(3)$, S1-(center of the phenylene ring $)-\$ 258.62$, S2-Cul-S1 $113.513(18), \$ 2-(\mathrm{Cul}-\mathrm{Il} 115.823(15)$, S1-Cul-Il 115.218(14), \$2Cul-IIA 102.216(14), Sl-Cul-IlA 94.839(14), II-Cul-IlA 112.394(9), Cul-Il-CulA 67.606(9). [Symmetry codes: $\mathrm{A}=-\mathrm{x}+$ $1,-y+1,-z+1]$ 
(a)

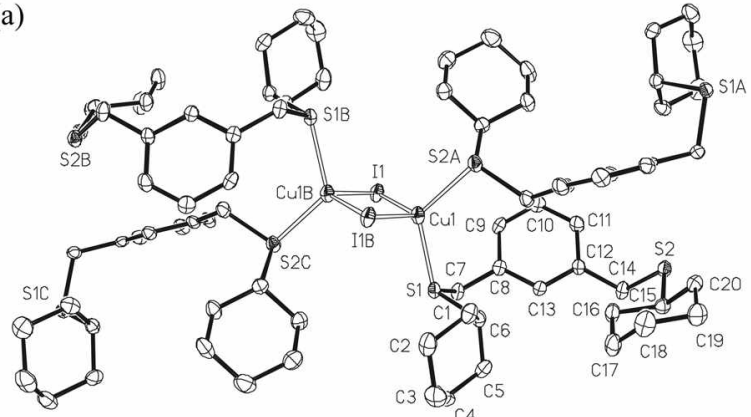



Figure 2. (a) Ottep diagram of 2 , showing coordination environment and (b) perspective view along the $a$-axis. Hvdrogen atoms are omitted for clarity. Selected bond lengths $(A)$ and bond angles (): Cul-CulB 2.7566(9), S1-S2 6.9171(13),Cul-S2A 2.3400(10), Cul-Sl 2.3523(11), Cul-Il 2.6224(5), Cul-IIB 2.6841(5), S1(center of phenylene ring)-S2 116.63, S2A-Cul-S1 122.11(4), S2A-Cul-Il 113.50(3), S1-Cul-Il 100.51(3), S2A-Cul-IIB 98.84(3), S1-Cul-IlB 105.26(3), Il-Cul-IlB 117.420)(17), Cul-IlCulB 62.581(17). [Svmmetry codes: $\mathrm{A}=-\mathrm{x}+3 / 2, \mathrm{y}+1 / 2,-\mathrm{z}+1 /$ $2 ; \mathrm{B}=-\mathrm{x}+2,-\mathrm{y}+2,-\mathrm{z}+1 ; \mathrm{C}=-\mathrm{x}+3 / 2, \mathrm{y}-1 / 2,-\mathrm{z}+1 / 2]$

S1 and S2 but also smaller angle (S1-center of xylene-S2) than those of $\mathrm{L}^{2}$ leads to the formation of the sandwich type complex. The adjacent 2D brick-wall layer is stacked on the top of this layer without offset in the $b c$-plane such that the continuous channels among the $a$-axis are formed. The distance of the adjacent layers is $c a .10 .4 \mathrm{~A}$ indicating no significant close contacts or other interactions between layers in the packing.

For complex 3. $\mathrm{Cu}_{4} \mathrm{I}_{4}$ units are located at the nodes of loop chain frameworks (Figure 3). Each copper atom in the cubane-tv'pe $\mathrm{Cu}_{4} \mathrm{I}_{4}$ unit is tetrahedrally coordinated to three $\mu_{3}$-iodide atoms and one sulfur donor of $\mathbf{L}^{3}$. Accordingly. four $\mathrm{Cu}-\mathrm{S}$ bonds between the cubane core and sulfur donors coming from four different $\mathbf{L}^{3}$ ligands occupy well-separated positions. and these adjacent ligand molecules are arranged spaciously to minimize steric hindrance. The cubane cores were interconnected with the ligands through $\mathrm{Cu}-\mathrm{S}$ bonds to produce $(2+2)$-type large metallacycles. leading to the formation of a 1D loop chain structure

Upon irradiation by UV light ( $\hat{\lambda}_{\mathrm{x}}=323 \mathrm{~nm}$ ), only 3 which has $\mathrm{CuI}$ cubane cores exhibits a bright green emission ( $\hat{\lambda}_{\text {max }}$ $=521 \mathrm{lun}$ ) in the solid state due to cluster-centered excited state by nixed halide-to-metal charge transfer character

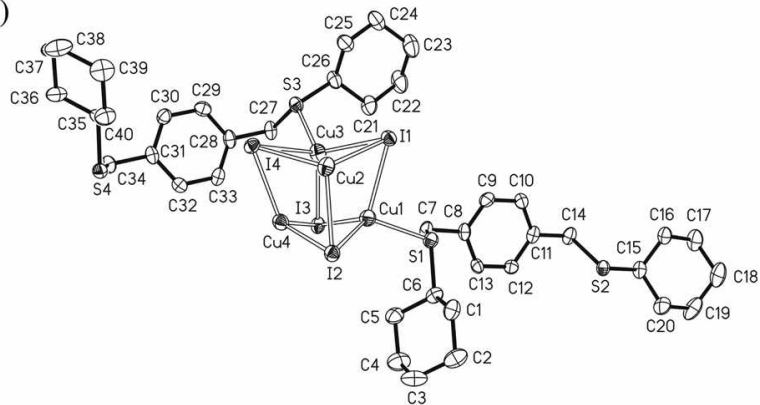

(b)

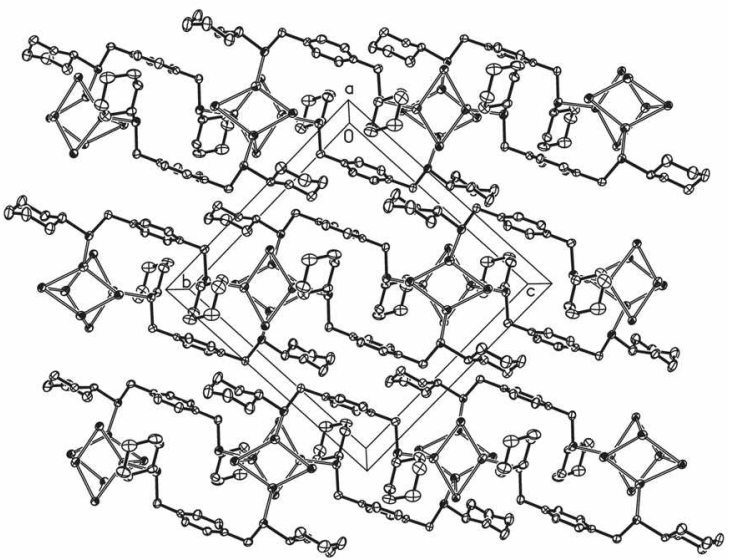

Figure 3. (a) Ortep diagram of 3, showing a cubane-like $\mathrm{CluI}_{4}$ core and (b) perspective view along the $a$-axis. Hydrogen atoms are omitted for clarity. Selected bond lengths $(A)$ and bond angles ("): $\mathrm{Cu}(1)-\mathrm{Cu}(2), 2.8568(8), \mathrm{Cu}(1)-\mathrm{Cu}(3), 2.8250(8), \mathrm{Cu}(1)-\mathrm{Cu}(4)$, $2.7719(8), \mathrm{Cu}(2)-\mathrm{Cu}(3), 2.7899(8), \mathrm{Cu}(2)-\mathrm{Cu}(4), 2.8046(8), \mathrm{Cu}(3)-$ $\mathrm{Cu}(4), 2.8303(8), \mathrm{Cul}-\mathrm{S1} 2.3162(12)$. Cu2-\$2A 2.3191(13). Cu3S3 $2.3161(13), \mathrm{Cu} 4-\mathrm{S} 4 \mathrm{~B}$ 2.3163(12), SI-(center of phenylene ring)-S2 130.15 , S1-(center of phenv lene ring)-S2 129.29. S1-CulI3 $106.45(4)$ I2-Cul-Il $115.77(2)$, S2A-CuL-Il $101.73(3)$, S3Cul3-Il 116.21(4), S4B-Cut-I3 119.53(4). [Symmetry codes: $\mathrm{A}=$ $-\mathrm{x}+1,-\mathrm{y}+1,-\mathrm{z}+1 ; \mathrm{B}=-\mathrm{x}+1,-\mathrm{y}+2,-\mathrm{z}]$

(Figure 4) ${ }^{6.12}$ The emission wave length is shorter than that of similar cubane cluster in the literature ${ }^{\text {ted }}$ This can be explained by higher energy level of LUMO with bonding character ${ }^{12}$ owing to longer $\mathrm{Cu}-\mathrm{Cu}$ distances (2.7719-2.8568 A) than those $(2.7290-2.7547 \AA)^{13}$ of the similar cubane cluster at $173 \mathrm{~K}$.

In summary, the present study represents that the entirely different coordination compounds 1-3 are induced by a structural difference in the ligands $\mathbf{L}^{1}-\mathbf{L}^{3}$ with the identical formula. The origin of the three different coordination compounds is due to the structural difference in the ligands $\mathbf{L}^{1} \cdot \mathbf{L}^{3}$. which have all different angles and distances between the two sulfur donors. In the case of 1 , the shortest distance and angle between the two sulfurs and the copper give rise to the formation of the sandwich type structure. However. longer $S \cdots S$ distance than $L^{1}$ and the planarity of four sulfur donors bound to the planar rhomboid $\mathrm{Cu}_{\mathrm{i}}-\mathrm{I}_{2}-\mathrm{Cu}$ unit in 2 prefer 2D layer structure. The ID loop chain structure $(3)$ is formed by the longest $\mathrm{S} \cdots \mathrm{S}$ distance and the spacious cubane-type $\mathrm{Cu}_{4} \mathrm{I}_{4}$ unit that allow connection between different $\mathrm{Cu}_{4} \mathrm{I}_{4}$ units and the packing of bulky cyclohexyl groups. 


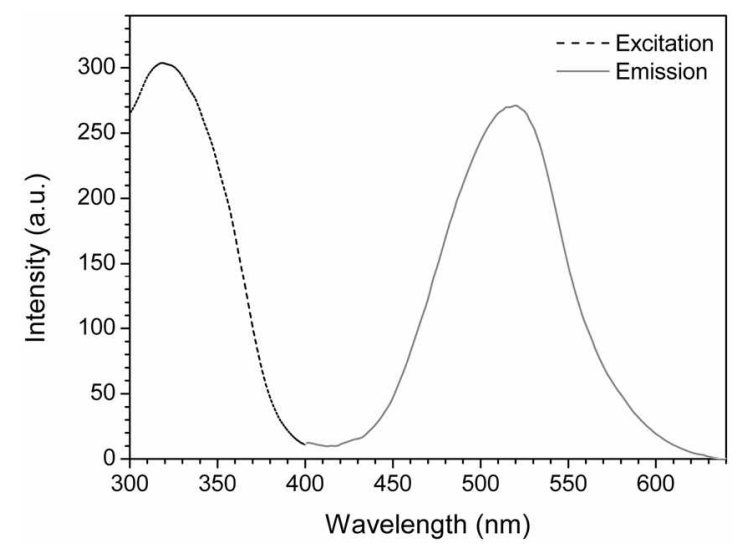

Figure 4. Solid state excitation (dashed line) and emission (solid line) spectra of 3 .

\section{Experimental Section}

The ${ }^{1} \mathrm{H}$ and ${ }^{13} \mathrm{C}$ NMR spectra were recorded with a Bruker Advance-300 (300 MHz) NMR spectrometer. Mass spectra were obtained on a JEOL JMS-700 spectrometer. The FT-IR spectra of the coordination polyners were measured with a Shimadzu FT-IR 8100 spectrometer. The elemental analy sis was carried out on a LECO CHNS-932 elemental analyzer. Solid state luminescence spectra were acquired with a Perkin Elner LS 50B spectrophotometer at the Central Laboratory of Gyeongsang National University. The excitation and emission spectra were corrected for the wavelengthdependent lamp intensity and detector response. respectively. The pulsed excitation source was generated using the 323 in of the Xenon lamp. Single cry stal diffraction data for 1-3 at $173 \mathrm{~K}$ were collected on a Bruker SMART CCD diffractometer equipped with graphite monochromated Mo $\mathrm{K}_{\alpha}$ radiation ( $\lambda=0.71073 \AA$ ). The cell parameters for the conpounds were obtained from a least-squares refinement of the spot (from 45 collected frames) using the SMART program. The intensity data were processed using the Saint Plus program. All of the calculations for the structure determination were carried out using the SHELXTL package (version 5.1) ${ }^{1+}$ In most cases, hydrogen positions were input and refined in a riding manner along with the attached carbons.

1,2-Bis(cyclohexylthiomethyl)benzene $\left(\mathbf{L}^{\mathbf{1}}\right) . \mathrm{NaOH}(0.80$ g. $0.02 \mathrm{~mol}$ ) was dissolved in water $(30 \mathrm{~mL})$ and cyclohexanethiol ( $2.32 \mathrm{~g} .0 .02 \mathrm{~mol})$ dissolved in THF $(20 \mathrm{~mL})$ was added and stirred. 1.2-bis(bromomethyl)benzene (1.75 g. $0.01 \mathrm{~mol}$ ) was dissolved in THF (20 $\mathrm{mL}$ ) and added to the cyclohexanethiol solution. After reflux for $2 \mathrm{~h}$. the reaction mixture was cooled and acidified by adding $6 \mathrm{M} \mathrm{HCl}$. Organic layer was collected and water layer was extracted with THF. The combined organic layers dried with anhydrous sodium sulfate were evaporated to give crude oil. Column chromatography (silica gel, $n$-hexane/ethylacetate $=$ $\left.50 / 50(\mathrm{v} / \mathrm{v}), \mathrm{R}_{\mathrm{f}} 0.4\right)$ gave pure oil $(3.08 \mathrm{~g}, 90 \%)$. IR (KBr, $v$. $\mathrm{cm}^{-1}$ ): 3061 w. 3018 w. 2926 s. 2853 s, 2660 w. 1697 w. 1600 w. 1489 m, 1448 s. 1339 m, 1263 m. 1200 m, 997 m. 885 m. 766 m. 716 m. 599 w. 563 w. ${ }^{1}$ H NMR (300 MHz.
$\mathrm{CDCl}_{3}$ ): $\delta 7.25$ (m. $4 \mathrm{H} \mathrm{Ar}$ ), 3.94 (s. $4 \mathrm{H} \mathrm{CH}_{2} \mathrm{ArCH}_{2}$ ), 2.67 (m, $2 \mathrm{H} \mathrm{SCH}), 1.2-2.1$ (m. $\left.20 \mathrm{H}, \mathrm{CH}_{2}\right) .{ }^{13} \mathrm{C} \mathrm{NMR}(75.4 \mathrm{MHz}$, $\left.\mathrm{CDCl}_{3}\right): \delta$ 136.78, 130.38. 127.17. 43.79, 33.52. 31.93, 26.05. 25.86. HREI-MS $(m / z)$ calcd. for $\mathrm{C}_{2(1)} \mathrm{H}_{310} \mathrm{~S}_{2}[\mathrm{M}]^{-}$: 334. 1789 : found: 334.1790 .

1,3-Bis(cyclohexylthiomethyl)benzene $\left(\mathrm{L}^{2}\right)$. This compound was prepared in a manner analogous to that for $\mathbf{L}^{\mathbf{1}}$. Column cluromatography (silica gel, $n$-hexane/ethy lacetate $=$ $\left.50 / 50(\mathrm{v} / \mathrm{v}), \mathrm{R}_{\mathrm{f}} 0.5\right)$ gave pure oil (3.00 g. 87\%). IR (KBr. $v$, $\mathrm{cm}^{-1}$ ): $3055 \mathrm{w}, 3024 \mathrm{w}, 2926 \mathrm{~s}, 2850 \mathrm{~s}, 2665 \mathrm{w}, 1697 \mathrm{w}$, $1604 \mathrm{w}, 1487 \mathrm{w}, 1448 \mathrm{~s}, 1340 \mathrm{w}, 1263 \mathrm{~m} .1202 \mathrm{~m}, 999 \mathrm{~m}$. 887 w, 796 w, $710 \mathrm{~m} .446$ w. ${ }^{1} \mathrm{H}$ NMR $\left(300 \mathrm{MHz} . \mathrm{CDCl}_{3}\right): \delta$ 7.25 (n. $4 \mathrm{H} \mathrm{Ar}$ ), 3.74 (s. $4 \mathrm{H} \mathrm{CH} \mathrm{CHCH}_{2}$ ). 2.56 (m. $2 \mathrm{H}$ $\mathrm{SCH})$. 1.2-2.1 (m. 20H, $\left.\mathrm{CH}_{2}\right),{ }^{13} \mathrm{C}$ NMR (75.4 MHz, $\left.\mathrm{CDCl}_{3}\right): \delta 139.14,129.16,128.53 .127 .24,42.94,34.51$, 33.39. 25.99. 25.86. HREI-MS $(m / z)$ calcd for $\mathrm{C}_{20} \mathrm{H}_{30} \mathrm{~S}_{2}$ $\left[\mathrm{M}^{-}: 334.1789\right.$; found: 334.1789 .

1,4-Bis(cyclohexylthiomethyl)benzene $\left(\mathrm{L}^{3}\right)$. This compound was prepared in a manner analogous to that for $\mathbf{L}^{\mathbf{1}}$. Column cluromatography (silica gel, $n$-hexane/ethy lacetate $=$ $\left.50 / 50(\mathrm{v} / \mathrm{v}), \mathrm{R}_{\mathrm{f}} 0.4\right)$ gave pure solid $(2.73 \mathrm{~g} .82 \%$ ). m.p. 67.5 ${ }^{\circ} \mathrm{C}$. IR (KBr, v, $\left.\mathrm{cm}^{-1}\right): 3046$ w. 3025 w. 2928 s, 2850 s, 2652 w. 1692 w. $1510 \mathrm{~m}, 1450 \mathrm{~s} .1341$ w. $1262 \mathrm{~m}, 1195 \mathrm{~m} .998 \mathrm{~m}$. $887 \mathrm{~m}, 845 \mathrm{~m} .744 \mathrm{~m}, 718 \mathrm{~m} .511 \mathrm{~m} .{ }^{1} \mathrm{H}$ NMR $(300 \mathrm{MHz}$, $\mathrm{CDCl}_{3}$ ): $\delta 7.27$ (n. $4 \mathrm{H} \mathrm{Ar}$ ), 3.75 (s. $4 \mathrm{H} \mathrm{CH}_{2} \mathrm{ArCH}_{2}$ ), 2.55 (m, 2H SCH), 1.2-2.1 (m. $20 \mathrm{H}, \mathrm{CH}_{2}$ ). ${ }^{12} \mathrm{C} \mathrm{NMR}(75.4 \mathrm{MHz}$, $\left.\mathrm{CDCl}_{3}\right): \delta 137.44 .128 .86 .42 .96 .34 .32 .33 .41,26.01,25.88$. HREI-MS (m/z) calcd. for $\mathrm{C}_{20} \mathrm{H}_{30} \mathrm{~S}_{2}\left[\mathrm{M}^{-}: 334.1789\right.$; found: 334.1791.

$\left[\mathrm{Cu}_{2} \mathrm{I}_{2} \mathbf{L}_{2}{ }_{2}\right](1)$ : An acetonitrile solution $(5 \mathrm{~mL})$ of $\mathbf{L}^{1}$ $(0.040 \mathrm{~g} .0 .10 \mathrm{mmol})$ was allowed to mix with an acetonitrile solution $(5 \mathrm{~mL})$ of $\mathrm{CuI}(0.019 \mathrm{~g} .0 .10 \mathrm{mmol})$, followed by dietlyyl ether diffusion. Colorless single crystals suitable for $\mathrm{X}$-ray analy sis were obtained. The crystals were filtered and washed with diethyl ether/acetonitrile $(\mathrm{v} / \mathrm{v}=\mathrm{l} / \mathrm{l})$ solution (0.048 g. 82\%). m.p. 182-184 ${ }^{\circ} \mathrm{C}$. IR ( $\left.\mathrm{KBr}, v_{,} \mathrm{cm}^{-1}\right)$ : 2923 s, 2848 m, 1493 w. 1447 m, 1333 w. 1262 w, 1205 w,


Calcd for $\mathrm{C}_{410} \mathrm{H}_{60} \mathrm{~S}_{4} \mathrm{Cu}_{2} \mathrm{I}_{2}: \mathrm{C}, 45.75 . \mathrm{H}, 5.76, \mathrm{~S}$ 12.21. Found: C. $45.67, \mathrm{H}, 5.98$. N. 3.23. S $11.98 \%$.

$\left[\mathrm{CuIL}^{2}\right]_{; 3}$ (2): This compound was prepared in a manner analogous to that for $1 .(0.050 \mathrm{~g} .85 \%)$. m.p. $182-185^{\circ} \mathrm{C}$. IR $\left(\mathrm{KBr}, v, \mathrm{~cm}^{-1}\right)$ : $2928 \mathrm{~s}, 2846 \mathrm{~m} .1597$ w, 1484 w. $1442 \mathrm{~m}$, 1346 w, 1264 w. 1222 w, 1160 w. 1084 w, 995 w. 905 w. 850 w. 806 w. $711 \mathrm{~m} .601$ w, $568 \mathrm{~m} .443 \mathrm{~m}$. [CuIL $\left.{ }^{2}\right]_{; 3}$ Anal. Calcd for $\mathrm{C}_{2 j} \mathrm{H}_{3} \mathrm{~S}_{2} \mathrm{CuI}: \mathrm{C}, 45.75$. H, 5.76. S 12.21. Found: C. $45.79, \mathrm{H}, 5.86 . \mathrm{S} 11.86 \%$.

$\left[\mathrm{Cu}_{4} \mathrm{I}_{4} \mathbf{L}_{2}\right]_{i 3}(3)$ : This compound was prepared in a manner analogous to that for 1 except for an amount of CuI $(0.038 \mathrm{~g}$. $0.20 \mathrm{mmol}$ ). (0.054 g. $69 \%$ ). m.p. $193-195^{\circ} \mathrm{C}$, IR (KBr, $v_{\text {; }}$ $\mathrm{cm}^{-1}$ ): 2923 s. $2846 \mathrm{~m} .1640 \mathrm{~s}, 1425 \mathrm{~s}, 1286 \mathrm{~m}, 1200 \mathrm{~s} .1025$ m. $985 \mathrm{~m}, 891 \mathrm{~m}, 557 \mathrm{w}, 527$ w. 496 w. $\left[\mathrm{Cu}_{4} \mathrm{~L}_{4}\left(\mathrm{~L}^{3}\right)_{2}\right]_{31}$ Anal. Calcd for $\mathrm{C}_{4 i} \mathrm{H}_{61} \mathrm{~S}_{4} \mathrm{Cu}_{4} \mathrm{I}_{4}:$ C. 33.57, H. 4.23. S 8.96. Found: C. $33.81, \mathrm{H}, 4.35 . \mathrm{S} 9.25 \%$.

Supplementary material. Supplementary crystallograplic data associated with 1-3 have been deposited at the Cam- 
bridge Crystallographic Data Centre [CCDC deposit numbers 649208 (1), 649209 (2), and 649210 (3)]. These data can be obtained free of charge on application to CCDC, 12 Union road. Cambridge CB2 IEZ. UK (fax: +44 1223336033 ; email: depositaccdc.cam.ac.uk), or electronically via www. ccdc.ac.ul/data_request/cif.

\section{References}

1. Seo, I. S.: Whang. D.; Lee. H.: Jum, S. I.: Oh, J.: Jeon. Y. J.: Kim, K. Nature 2000. 404,982.

2. Ford P. C.: Cariati, E.: Bourassa, J. Chem. Rev. 1999. 99, 3625 , and references therein.

3. Robin. A. Y: Fromm. K. M. Coord Chem. Rev 2006. 250. 2127. and references therein.

4. (a) Kondo, M.: Yoshitoni, T: Seki, K.: Matsuzaka. H: Kitagawa, S. Angew: Chem. Wht. Ed. 1997, 36. 1725. (b) Park. H. Jeong. M. H.: Kim. J. C. Lough, A. J. Bull. Korean (7hem. Soc. 2007, 28 . 303. (c) Yuan. Q.: Liu. B. Bull. Koreun Chem. Soc. 2006, 27, 150. (d) Kaneko. W.: Ohba. M.: Kitagawa. S. J. Am. Chem. Soc. 2007. 129. 13706. (e) Shimomura. S: Horike. S: Matsuda. R: Kitagawa, S. J. Am. Chem. Soc. 2007. 129, 10990.

5. (a) Park. K.-M: Yoon. I.: Seo, J.: Lee. J.-E.: Kim. J : Choi. K. S.: Jung, O.-S: Lee, S. S. Crystal Growth \& Desigh 2005. 5, 1707. (b) Araki. H.: Tsuge. K.: Sasaki. Y: Ishizaka. S.: Kitamura. N. Inorg. Chem. 2005. 44.9667. (c) Cariati. E.: Roberto. D.: Ugo. R: Ford. P. C.: Galli. S.: Sironi. A. Inorg. Chem. 2005 44. 4077.

6. (a) Kim. T. H.: Lee. K. Y.: Shin. Y. W.: Moon. S.-T.: Park. K.-M: Kim, J. S. Kang. Y: Lee. S. S.: Kim, J. Inorg. Chem. Commm. 2005, 8, 27. (b) Hu. S.: Tong. M.-L. Dalton Trans. 2005. 1165

7. Xie, Y.-B.; Ma. Z.-C.: Wang D. J. Mol Struct 2006, 784. 93

8. Ohi. H.: Tachi. Y: Kunimoto. T.: Itoh. S. Dolton Trants. 2005. 3146
9. Kim1. T. H.: Shin. Y. W.: Kim. J. S.: Lee. S. S.: Kimn. I. Inorg. Chent Conmum. 2007. 10.717

10. (a) Kim. T. H.: Shitr. Y. W. Lee. S. S.: Kim. J. Inorg. Chent Commun. 2007. 10, 11. (b) Kim, T. H.: Shin, Y. W.; Lee, S. S.; Kim. J. Anal. Sci. 2006. 22, .287

11. Crystallographic data for $\mathrm{C}_{4(1} \mathrm{H}_{40} \mathrm{Cu}_{2} \mathrm{I}_{2} \mathrm{~S}_{4}$ (1): FW $=1050.00$. monoclinic. space group $P 2_{1}, c$ (n10. 14). $a=10.9341(5) . b=$ $8.8896(4) . c=22.1228(10) \AA . \beta=97.2980(10)^{\circ} . V^{\prime}=2132.91(17)$ $\AA^{3} \cdot Z=2 . D_{c}=1.635 \mathrm{~g} \mathrm{~cm}^{-3} \cdot T=173(2) \mathrm{K} \cdot F(000)=1056$ variables refined with 5000 independent reflections $\left(R_{\mathrm{utt}}=0.0162\right)$ to final $R$ indices $[I \% 2 \sigma I)]$ of $R_{1}=0.0191$ and $w R_{2}=0.0458$. and $\mathrm{GOF}=1.043$, absorption correction: $\operatorname{SADABS}\left(T_{\min } T_{\max }=\right.$ 0.761239 )

Crystallographic data for $\mathrm{C}_{2(1 \mathrm{H}} \mathrm{H}_{3(1} \mathrm{CuIS}_{2}(2)$ : $\mathrm{FW}=525.00$. monoclitic. space group $P 2_{1}$ n (no. 14). $a=11.8523(9) . b=8.6406(7)$. $c=20.0139(16) \AA, \beta=92.853(2)^{\circ}, I^{\circ}=2047.1(3) \AA^{3} . Z=4 . D_{c}=$ $1.703 \mathrm{~g} \mathrm{~cm}^{-3} . T=173(2) \mathrm{K} . F(000)=1056$ variables refined with 4787 independent reflections $\left(R_{\text {int }}=0.0708\right)$ to final $R$ indices $[I$ $2 \pi I D]$ of $R_{1}=0.0330$ and $w R_{2}=0.0584$. and $\mathrm{GOF}=0.882$. absorption correctionl: $\psi$-sean1 $\left(T_{\text {min }}=0.1557 . T_{\max }=0.3297\right)$. Crystallographic data for $\mathrm{C}_{+0} \mathrm{H}_{60} \mathrm{Cu}_{4} \mathrm{I}_{+} \mathrm{S}_{+}(3): \mathrm{FW}=1430.88$ triclinic, space group $P .1$ (no. 2), $a=11.2171(5), b=14.3433(7)$. $c=14.8236(7) \AA, \alpha=92.2170(10), \beta=90.4880(10), \gamma=$ $93.7800(10)^{\circ} . \Gamma^{\circ}=2377.86(19) A^{3}, Z=2, D_{c}=1.998 \mathrm{~g} \mathrm{~cm}^{-3}, T=$ $173(2) \mathrm{K} . F(0,00)=1384$ variables refined with 10865 independent reflections $\left(R_{\text {int }}=0.0504\right)$ to final $R$ indices $\left.[I \% 2 \sigma I)\right]$ of $R_{\mathrm{L}}$ $=0,0321$ and $w R_{2}=0,0628$. and $\mathrm{GOF}=1.008$. absorption correction: $\psi$-scan $\left(T_{\text {mint }}=0.1967 . T_{\max }=0.3080\right)$

12. Vitale, M.: Palke. W. E.: Ford. P. C. J. Phus. Chem 1992, 96. 8329.

13. Kiml. T. H. Ph. D. Disserfation: Gyeongsang National University. 20066.

14. Sheldrick. G. M. Bntket SHELITL-PC. Version 5.10. BrukerAnalytical X-ray Services: Madison. WI, 1998. 